\title{
On the Cultivation of Students' Creative Ability in College Art Education
}

\author{
Nan Zhou, Xinyi Zhou \\ Zhejiang Normal University, Jinhua, China \\ Email: 81303851@qq.com
}

How to cite this paper: Zhou, N. and Zhou, X.Y. (2021) On the Cultivation of Students' Creative Ability in College Art Education. Open Access Library Journal, 8: e7705. https://doi.org/10.4236/oalib.1107705

Received: June 27, 2021

Accepted: August 10, 2021

Published: August 13, 2021

Copyright (c) 2021 by author(s) and Open Access Library Inc.

This work is licensed under the Creative Commons Attribution International License (CC BY 4.0).

http://creativecommons.org/licenses/by/4.0/

\begin{abstract}
Art teaching in schools is a key measure for students to improve their innovative ability. At present, teachers need to formulate various objectives of art education and teaching in colleges according to the specific conditions of students, while the purpose of art education and teaching in college students under the new curriculum is to combine students' personality characteristics, constantly improve students' personalized innovation, optimize the way of college art education, and provide reference for the future college art education.
\end{abstract}

\section{Subject Areas \\ Art, Higher Education}

\section{Keywords}

University, Fine Arts Education, Innovation Ability, Cultivation

\section{Introduction}

College art education occupies a very important position in the university education. It can not only edify the student's sentiment, stimulate the student's thinking, but also promote the student's physical and mental health, improve the student's accomplishment, release the student's pressure, and the fine arts education and other disciplines have significant differences. Art is another unique way for us to observe the world. Compared with the oppressive learning in cultural classes, art studies are relatively free and attach importance to individual expression. Art teaching for college students means that teachers provide art works for college students and students constantly improve their ability to apply art skills. 


\section{Problems Existing in the Cultivation of Students' Innovative Ability in College Fine Arts Education}

Mobile phones for contemporary students have become an indispensable part of life. A large number of pictures on the Internet limit students' imagination and innovative thinking. How to change this situation has become the main problem of college art education. Art courses in the actual teaching process have not been fully valued by the school administrators. In most middle schools in rural areas, the study of fine arts has never been carried out, and most of the classes are still in the mode of blackboard + chalk. In addition, there are insufficient teaching AIDS. Most schools in remote areas do not have the necessary drawing tools for classes, which the schools do not pay attention to and parents cannot afford. In the teaching process of teachers, art teaching lacks a certain competitive mechanism, which is because teachers' planning for art teaching is not clear enough, which will become problems in college art education.

\section{Cultivation Strategy of Students' Innovation Ability in College Fine Arts Education}

\subsection{Pay Attention to the Use of Color and Line Collocation to Enhance the Artistic Value of Art Works}

Art teachers take art teaching as their own duty, and in the teaching and explanation of art works, they need to fulfill their responsibilities, including the explanation of preparatory work [1]. Try to avoid restricting students' thinking, mainly to diffuse students' imagination as the main purpose, improve students' personalized development. The application of color in art works is subjective, and the most excellent color collocation is the connotation expression of the author's mood and mood. At present, art teachers in schools need to base themselves on daily teaching and accumulation. For art works, they should first of all be natural and decorative. Paying attention to the collocation of colors and lines to enhance the artistic value of art works [2]. At the same time, on the premise of pay attention to color and line, we also need to consider the color and degree of harmonic to appreciate the art works of factors, therefore, for the color and tonal collocation, you need to first clear artwork of primary and secondary part is clear, rich in content, will be able to continue to increase the artistic value of works of fine art, so as to improve the efficiency of the accumulation and creation of art works.

Under the personalized education of teachers, schools and the country should also attach importance to the physical and mental development of students, and should fully implement the national educational policy to carry out the comprehensive development of compulsory education for students. It is not advisable to only attach importance to culture while giving up the all-round development of other aspects. If students are forced to exclude knowledge other than cultural courses and ignore students' various abilities and interests, children's nature and creativity will be gradually strangled. 


\subsection{Clarify the Background and Significance of the Creation of Art Works and Further Grasp the Colors and Tones in the Works}

When appreciating art works, students should start from the emotion that the author wants to express, which requires teachers to increase practical activities and cultivate students' creative ability. In the process of teaching art works, the background and significance of creating this picture should be made clear first, and the choice of color and tone should be further made. This article thinks that teachers need to grasp the overall tone of the art works, so that the visual experience of a large area will bring a very distinct feeling to the viewer. In art works, bright colors give people positive and optimistic feelings, while dark colors give people depressed feelings.

\section{Conclusion}

This article based on the university art education problems of middle school students' innovation ability training, is further discussed from the following two aspects of the university art education of middle school students' innovation ability training strategy, and paying attention to the collocation of color and line that is used, respectively, to enhance the art of art value, clear writing background and significance of fine arts, to further grasp the color tone of the work.

\section{Conflicts of Interest}

The authors declare no conflicts of interest.

\section{References}

[1] Hu, J. (2020) Practice and Exploration of Color Teaching in Art Education-Comment on Exploration of College Art Education in the Perspective of Innovation. Science and Technology of Chinese Universities, No. 380, 115.

[2] Jia, X.Y. and Luo, Y. (2021) Discussion on the Copyright of Online Open Courses: A Case Study of the Course of Entrepreneurship: Taking Design Thinking as an Example. Social Science Frontiers, 10, 9. https://doi.org/10.12677/ASS.2021.103107 